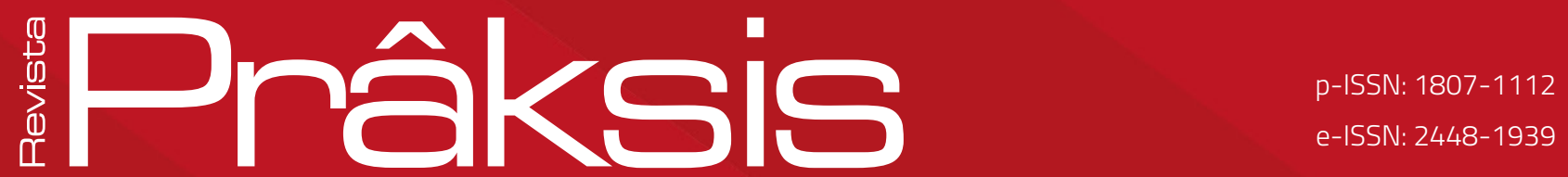

Recebido em: 18 de setembro de 2018 Aprovado em: 20 de fevereiro de 2019 Sistema de Avaliação: Double Blind Review RPR |a. 16 |n. 2 |p. 34-56| mai./ago. 2019 DOI: https://doi.org/10.25112/rpr.v2i0.1761

\title{
A CRIMINALIzAÇÃo da hOMOFOBIA NO BRASIL: ANÁLISE JURISPRUDENCIAL E DOUTRINÁRIa
}

THE CRIMINALIZATION OF HOMOPHOBIA IN BRAZIL: JURISPRUDENTIAL AND DOCTRINE ANALYSIS

\section{Henrique Alexander Grazzi Keske}

Doutor em Filosofia pela Universidade do Vale do Sinos (São Leopoldo/Brasil).

E-mail: hiquekeske@hotmail.com.

\section{Veronica Coutinho Marchini}

E-mail: verinho7@gmail.com. 


\section{RESUMO}

O objetivo central deste artigo é analisar, por meio da análise jurisprudencial e doutrinária, que o direito à liberdade de expressão não é óbice para se criminalizar a homofobia no Brasil. Neste diapasão, verificase que não há, no Brasil, lei que criminalize a homofobia e o discurso de ódio. Assim sendo, por meio da análise do HC 84.424/RS, será aludido o conceito de racismo desenvolvido pelo STF, bem como o entendimento de nossa Corte de que o direito à liberdade de expressão possui limites, em relevância quando o objetivo é incitar a violência, assim como a menção ao discurso de ódio. Tal análise é imprescindivel, tendo em vista que alguns dos projetos de lei já apresentados no Brasil que versaram sobre criminalizar a homofobia, ou que ainda estão em tramitação, utilizaram-se do conceito de racismo apresentado no $\mathrm{HC}$ citado, como justificativa para se ter uma lei protegendo os LGBTI em caso de homofobia. Por fim, ao longo do artigo, se demonstrará a morosidade com que o Legislativo brasileiro trata os projetos de lei que versam sobre criminalizar a homofobia, visto que o Brasil, mesmo consagrando em sua Constituição o Estado laico, conta com muita presença religiosa em seu Congresso, prejudicando, assim, o andamento de tais projetos, com a justificativa de cerceamento do direito à liberdade de expressão.

Palavras-chave: Homofobia. Liberdade de expressão. Discurso de ódio. Racismo.

\section{ABSTRACT}

The main objective of this article is to analyze, through jurisprudential and doctrinal reviews, that the right of freedom speech it is not an obstacle to criminalize the homophobia in Brazil. In this passage, ensure that there is no law in Brazil that criminalize the homophobia and the hate speech. So, through analysis of HC 84.424/RS will be quoted the concept of racism developed by the Federal Supreme Court, as well as the understanding of our Court that the right of freedom speech has limits, mainly when the goal is to urge the violence, as well as the mention of hate speech. Such an analysis is indispensable, considering that some of the draft bills already submitted in Brazil that was related about to criminalize the homophobia, or those which is still in processing, adopted the concept of racism developed on the HC above mentioned, to justify a law protecting the LGBTI in case of homophobia. Finally, throughout the article, will be demonstrated the slowness with which the Brazilian legislative treats the drafts bills that deals about to criminalize the homophobia, in view of the fact that Brazil, even consecrated in its Constitution as a laic State, it contains a large amount of religious presence in the Congress, thereby impairing, the progress of such processes, with the justification of restriction the right to freedom speech.

Keywords: Homophobia. Freedom of speech. Hate speech. Racism. 


\section{INTRODUÇÃO}

$\mathrm{O}$ ato de discriminar é algo constante e presente em nossa sociedade, desde os primórdios das civilizações. Pode-sedizer quesetratadeumarealidadehistórica. Discriminavam-seasmulheres, asbruxas, os negros, os judeus, os homossexuais, entre outras minorias. Tais discriminações, em que pese todo o contexto histórico, ainda é algo visível em nossa realidade atual. Justamente por serem consideradas minorias, sofreram e ainda sofrem, numa luta constante pelo simples reconhecimento da igualdade.

Neste contexto, principalmente após os horrores causados pela Segunda Guerra Mundial, e com o reconhecimento dos direitos humanos, esse tema passou a ser relevante para o Direito. Vários tratados e declarações reconhecendo os direitos humanos começaram a surgir, sendo o marco inicial a Declaração Universal dos Direitos Humanos da ONU, no ano de 1948.

Contudo, tal reconhecimento não fez cessar ou diminuir alguns preconceitos. Nesse contexto, a discriminação e o preconceito a determinados grupos começaram a ser tratados pelo Direito como um assunto constitucional. Dito isto, ainda em relação à questão da discriminação, os grupos considerados sofredores de tais preconceitos começam, então, a terem seus direitos garantidos. Não obstante, o preconceito não cessa, mas se torna velado, pois haverá sanção no campo do direito para quem pregar tal fato discriminatório.

Surge então o tema do discurso de ódio, que nada mais é, conceituando de forma simplista, do que a verbalização de preconceitos com o intuito de incitar a violência. Este tema também é conhecido como hate speech na doutrina estrangeira. 0 discurso de ódio recebe algumas críticas, haja vista que proibir tal discurso estaria colidindo com o direito à liberdade de expressão. Contudo, conforme será visto neste trabalho, tal afirmação é incorreta, posto que não há direito absoluto no Brasil.

Eénestecenário que se insere o grupo LGBTI. Tal grupo pede a igualdade de direitos. A homossexualidade deve ser considerada como um fato social que está na sociedade desde a Antiguidade. Numa sociedade heteronormativa, os indivíduos que não se inserem nesta dicotomia de sexo e gênero, homem e mulher, masculino e feminino, não merecem ser tratados da mesma forma que os heterossexuais. Contudo, há que se citar que a homossexualidade era considerada natural na Grécia Antiga e que somente com a ascensão da Igreja Católica, e seu conceito de Sodomia, que se iniciou, então, uma caça aos homossexuais.

Após tais acontecimentos, e com o decorrer dos tempos, verifica-se que muitos países já reconhecem o direito de igualdade entre LGBTI e heterossexuais. Entretanto, ainda há muito a ser analisado, pois mesmo com toda a evolução histórica e jurídica, o que se verifica é a discriminação, e neste caso, em quase sua totalidade, não velada, pura e simplesmente por convicções arcaicas em relação à procriação e à religião. A justificativa é a de que a afetividade entre pessoas de mesmo sexo não é suficiente para a constituição 
familiar. Importante referir que tal concepção há muito já não é mais atual, inclusive no campo jurídico, haja vista o reconhecimento do afeto como requisito essencial em casos de direito de família. Isto posto, surge então a indagação: não somos todos iguais em direitos e obrigações? Então, qual a razão para o não reconhecimento de direitos da população LGBTI, e mais, qual o motivo para não haver lei que criminaliza o ato homofóbico verbal e físico?

Nesse sentido, torna-se ponto crucial uma breve análise do Habeas Corpus 84.424/RS, julgado pelo STF no ano de 2003, conhecido como caso Ellwanger, pois foi neste HC que o STF cunhou o conceito de racismo e citou o discurso de ódio. Neste julgamento, os Ministros do STF analisaram o caso do escritor/ editor que afirmava, em sua defesa, que os judeus não constituíam uma raça e que, desta maneira, não teria cometida racismo com a publicação de seu livro antissemita, bem como que estaria protegido pelo direito à liberdade de expressão. A solução deste caso é considerada emblemática, por envolver o discurso de ódio. Com base neste julgamento, que também afirmou que não há direito absoluto, ou seja, que a liberdade de expressão deve ser limitada quando incitar o ódio, vários projetos para criminalizar a homofobia foram feitos, usando justamente o conceito de racismo social.

Nesse sentido, neste artigo, primeiramente, será analisado o conceito de homofobia e, após, será apresentado o histórico de todos os projetos de lei já apresentados no Brasil que versavam sobre a criminalização da homofobia. Muitos já foram arquivados, mas serão citados, e também os que ainda estão tramitando, bem como suas justificativas. Por fim, será mencionado o Projeto de Lei que pela primeira vez no Brasil conceitua discurso de ódio. Destarte, o que se verifica é que se trata de um assunto tão atual e que fenece à margem da sociedade, sendo menosprezado, mesmo com a constatação do aumento da criminalidade contra a população LGBTI.

\section{A CRIMINALIZAÇÃO DA HOMOFOBIA NO BRASIL}

\subsection{HISTÓRICO DOS PROJETOS DE LEI ANTI-HOMOFOBIA NO BRASIL}

Não há como dissertar sobre projetos de criminalização da homofobia sem antes trazer à baila o conceito de homofobia. Tal palavra, por si só, já levanta inúmeras teorias e até mesmo contradições. 0 presente subtítulo trabalhará tais conceitos, sem detalhar os pormenores de tais fatos, mas apenas pincelar seus traços mais essenciais, para que possamos alcançar e entender os projetos que tentam criminalizar a homofobia no Brasil, principalmente a ligação entre homofobia, discurso de ódio e racismo, visto que, em sua grande parte, há a tentativa de aproximação dos conceitos, tendo em vista o conceito de racismo cunhado pelo STF, conforme já abordado. Também serão vistos os inúmeros projetos para criminalização da homofobia já apresentados no Brasil. Não serão tratados a fundo tais projetos, nem será feita uma 
análise pormenorizada, mas somente os fatos principais que demonstram a morosidade do Congresso Nacional em tomar a frente neste tipo de crime.

\subsubsection{Conceito de homofobia}

A palavra homofobia foi criada em 1971 por K.T. Smith que tentou analisar os traços da personalidade homofóbica, porém, em 1972 G. Weinberg, psicólogo norteamericano, estabeleceu que homofobia é "o receio de estar com um homossexual em um espaço fechado e, relativamente aos próprios homossexuais, o ódio por si mesmos" (WEIBERG, 2015, p. 21).

Tal conceito foi considerado insatisfatório pelo entendimento de que poderia significar o receio do semelhante, ao invés de somente receio do homossexual. À vista disso, em 1980 surge, então, uma diferenciação entre homofobia e homonegatividade, sendo esta última não somente a aversão já vivenciada em atos de homofobia, mas, como explica Borillo, principalmente "ao conjunto das atitudes cognitivas de cunho negativo para com a homossexualidade nos planos social, moral, jurídico e/ou antropológico". Desta forma, o termo homofobia acaba por designar dois aspectos diferentes na mesma realidade: a dimensão pessoal, afetiva, que rejeita os homossexuais; e a dimensão cultural de natureza cognitiva, que não despreza o indivíduo homossexual, mas, sim, o fenômeno psicológico e social da homossexualidade. Esta diferenciação fica muito clara quando há a tolerância e até mesmo simpatia com os homossexuais, porém quando o assunto é alguma política de igualdade, tal assunto é considerado inaceitável (BORILLO, 2015, p. 22).

O termo homofobia também possui o sentido de algo clínico, medicalizante, na medida em que há a associação da homofobia com atitudes e emoções psicopatologicamente determinadas, ou seja, quando se usa o termo homofobia há a referência a emoções negativas, como ódio, aversão, repulsa, medo, e essas emoções poderiam ser explicadas pelo receio da própria pessoa homofóbica ser homossexual, ou que pensem que ela seja. Porém, este discurso acaba por travar uma batalha cruzada, conforme cita Junqueira, qual seja, "de um lado, os que ainda definem a homossexualidade como doença e, de outro, os que rechaçam essa afirmação dizendo que a doença seria a homofobia." Porém, entendê-la assim, pode simplificar e minimizar os efeitos, além de manter e fortalecer, de uma forma laica e científica, o preconceito (JUNQUEIRA, 2007, p. 4-6).

A homofobia como aversão fóbica seria então um sintoma que surge para evitar uma situação de perigo, tendo neste contexto a reação homofóbica violenta como matriz de sujeitos que possuem conflito interno com seus próprios sentimentos homossexuais. Seria a projeção de um sentimento homossexual insuportável e até mesmo inconsciente. Para isso, o modo de combater, então, a homofobia, seria a adoção 
de terapias psicológicas e o encorajamento de conviver e conhecer a realidade do outro, a fim de superar eventual preconceito ou ignorância (RIOS, 2007, p. 199-120).

Há então uma desvinculação da homofobia como conjunto de emoções negativas, porém, contrapondo a qualquer vinculação patologizante. Junqueira, então, diz que:

[...] a noção de homofobia pode ser estendida para se referir a situações de preconceito, discriminação e violência contra pessoas (homossexuais ou não) cujas performances e ou expressões de gênero (gostos, estilos, comportamentos etc.) não se enquadram nos modelos hegemônicos postos por tais normas (JUNQUEIRA, 2007, p. 8-9).

Desta forma, há a exclusão no conceito de homofobia da ideia do medo irracional da homossexualidade; e o que se verifica é a análise, então, da violência homofóbica, com a divisão em violência simbólica, institucional e interpessoal (CARVALHO, 2012, p. 187-212).

Conforme elucida Carvalho, a violência homofóbica interpessoal ou individual seriam os atos de violência real contra a pessoa e até mesmo a violência sexual. A violência homofóbica institucional ou homofobia de Estado seria "a criminalização e a patologização das identidades não heterossexuais"; e a violência homofóbica simbólica parte da "construção social de discursos de inferiorização da diversidade" (CARVALHO, 2017, p. 257).

Hátambém ahomofobiageral, que, conforme Borillo, éa "discriminação depessoasem razãodeseu sexo (macho/fêmea) e, mais particularmente, de seu gênero (feminino/masculino), "ou seja, não importando a real orientação sexual do indivíduo. Já a homofobia específica nada mais é do que a intolerância aos gays e lésbicas (BORILLO, 2015, p. 34).

De tudo exposto, cabe ainda explicitar a ordem sexual que diferencia os homens das mulheres. 0 sexismo nada mais é que a discriminação em relação às mulheres, tanto por homens quanto por mulheres. Legitima a violência contra mulheres, bem como a todos que se enquadrem numa posição feminilizada (SMIGAY, 2002).

Há, assim, uma ordem sexual que subordina o feminino ao masculino bem como hierarquiza a sexualidade, tornando, desta maneira, a heterossexualidade como a forma padrão, normatizada. Esta forma de dominação, Borillo chama de heterossexismo, ou seja, "a crença da existência de uma hierarquia das sexualidades, em que a heterossexualidade ocupa a posição superior" (BORILLO, 2015, p. 31).

O heterossexismo, conforme Rios, "é institucionalizado como norma social, política, econômica e jurídica", e cria, portanto, um parâmetro para a concessão e reconhecimento de benefícios sociais, políticos e econômicos. Por consequência, a homofobia, assim como o heterossexismo, têm fundamento na diferenciação que existe na divisão dos sexos e na diversidade de gêneros. Como descrito por Rios: 
A homofobia revela-se como contraface do sexismo e da superioridade masculina, na medida em que a homossexualidade põe em perigo a estabilidade do binarismo das identidades sexuais e de gênero, estruturadas pela polaridade masculino/feminino. Toda vez que esta diferenciação for ameaçada [...] apresentar-se-á todo um sistema de ações e reações prévio ao indivíduo, no qual ele está imerso, nele se reproduz e dele vai muito além: trata-se do caráter institucional da homofobia como heterossexismo (RIOS, 2007, p. 31).

Para um conceito polissêmico e plural, vale citar a definição de homofobia proposta por Borillo:

A homofobia pode ser definida como a hostilidade geral, psicológica e social contra aquelas e aqueles que, supostamente, sentem desejo ou têm práticas sexuais com indivíduos de seu próprio sexo. Forma específica do sexismo, a homofobia rejeita, igualmente, todos aqueles que não se conformam com o papel predeterminado para seu sexo biológico. Construção ideológica que consiste na promoção constante de uma forma de sexualidade (hétero) em detrimento de outra (homo), a homofobia organiza uma hierarquização das sexualidades e, dessa postura, extrai consequências políticas (BORILLO, 2015, p. 34).

Um aspecto interessante, o qual não pode ser esquecido é o fato de que os conceitos abordados até aqui excluem, em sua grande parte, a tradicional ideia do medo irracional da homossexualidade, pois isto traria um peso patologizador a tal conceito, e seguem a linha de estigma e discriminação contra homossexuais. Dito de outra forma, há uma delimitação do conceito de violência homofóbica que acaba por anteferir as formas de violência interpessoal. Porém, o que deve haver é tornar a homofobia como ato concreto que é praticado por uma pessoa, e que, a partir disto, há então a individualização da conduta homofóbica e, por conseguinte, a responsabilização jurídica de quem cometeu tal ato. A esse respeito, citam-se as palavras de Carvalho, o qual esclarece o aspecto mais importante do problema em análise, quando afirma que "seria possivel conceituar crime homofóbico como as condutas ofensivas a bens jurídicos penalmente protegidos, motivadas pelo preconceito ou pela discriminação contra pessoas que não aderem ao padrão heteronormativo" (CARVALHO, 2012, p. 187-212).

Como questão relevante, pode-se citar, ainda, o esclarecedor conceito de heteronormatividade que Junqueira apresenta:

Mais do que a homofobia, mas sem dela se dissociar, a heteronormatividade, ao se relacionar à produção e à regulação de subjetividades e relações sociais, parece chamar mais a atenção para os nexos entre um conjunto de eixos que atuam na construção, legitimação e hierarquização de corpos, identidades, expressões, comportamentos, estilos de vida e relações de poder. Especial ênfase pode então ser posta nos fortes vínculos da heteronormatividade com outros arsenais normativos, normalizadores e 
estruturantes que agem nesses mesmos terrenos, tais como o racismo, o sexismo, a misoginia, a xenofobia, o classismo, a corpolatria, entre outros (JUNQUEIRA, 2007, p. 8-9).

Com base nesse conceito apresentado, pode-se constatar que alguns autores consideram a homofobia similar com outras formas de inferiorização como o racismo, o antissemitismo e o sexismo. 0 objetivo de todas essas formas, conforme abordagem de Borillo "consiste sempre em desumanizar o outro, em torná-lo inexoravelmente diferente" (BORILLO, 2015, p. 35).

0 antissemitismo provém de traços culturais e por identificações genealógicas e a emergência dos regimes totalitários, mormente na Europa. O sexismo é a distinção entre homem e mulher no sistema binário de gênero. Por fim, o racismo é baseado na cor de pele que funda a ideologia da escravidão (OLIVA, 2015, p. 39).

Em que pese essas semelhanças, não há como não identificar uma diferença relevante, pois o sexismo, o racismo e o antissemitismo, todos têm marcadores corporais, já na homossexualidade, conforme Rios, "salvo auto-identificação ou atribuição por terceiros", não há marcadores visuais, que diferenciem homossexuais de heterossexuais (RIOS, 2007, p. 123).

De certa forma, é importante que se faça uma breve distinção, conforme Borillo destaca:

Diferentemente de outras formas de hostilidade, o que caracterizaria a homofobia, portanto, é o fato de que ela visa, sobretudo, indivíduos isolados, e não grupos já constituídos como minorias. 0 homossexual sofre sozinho o ostracismo associado à sua homossexualidade, sem qualquer apoio das pessoas à sua volta e, muitas vezes, em um ambiente familiar também hostil. Ele é mais facilmente vítima de uma aversão a si mesmo e de uma violência interiorizada, suscetíveis de levá-lo até ao suicídio (BORILLO, 2015, p. 40).

Por conseguinte, racismo e homofobia são fenômenos que confluam e se fortificam, contudo, a prática e o discurso são discrepantes, a julgar por nossa sociedade em que tem o racismo como algo proibido e punido, enquanto o preconceito a homossexuais, bissexuais e transgêneros operam até mesmo como forma de confirmação e aceitação entre grupos (JUNQUEIRA, 2007, p. 8-9).

\subsubsection{Propostas de regulação da homofobia apresentadas no Brasil}

Em 1987, na Assembleia Constituinte, João Antônio Mascarenhas, representante do Grupo Triângulo Rosa, organização gay à época, foi convidado a falar no Congresso Nacional. Seu pleito era simples e 
único, a inclusão da proibição de discriminação por orientação sexual na Constituição Federal, em seu artigo $3^{\circ}$, inciso IV. Contudo, tal pauta teve 130 votos a favor e 317 contra, não tendo sido, então, incluída na nossa Carta Magna (MASIERO, 2017).

Tal participação na Assembleia Constituinte se deu através do auxílio do Conselho Nacional dos Direitos da Mulher. Vale dizer que os movimentos feministas já tinham uma agenda e ação bastante estruturadas à época. Quanto à participação de homossexuais, houve uma preocupação dos Constituintes com tal fato, visto que poderia gerar incredibilidade aos trabalhos. Contudo, João conseguiu proferir o pedido (OLIVEIRA, 2013).

Os debates proferidos após a exposição de João valem o registro, para demonstrar o apedeutismo que, infelizmente ainda se encontra no Brasil. Um Constituinte afirmou que não havia problemas com as homossexuais femininas, mas somente com os homossexuais masculinos, por serem mais extravagantes, do mesmo modo que considerava os homossexuais como corruptores de menores, e se houvesse tal proteção aos homossexuais na Constituição, poderia gerar um aumento no número de homossexuais. Outro questionou sobre o termo "orientação sexual", afirmando que poderia ser usado por professores gays para impelir os alunos ao homossexualismo, termo usado à época, ou como depois justificou, o termo "orientação sexual" passaria uma ideia de que o aluno poderia escolher entre ser homossexual ou não (OLIVEIRA, 2013).

Terminada a fase de participação popular, deu-se, então, os debates das propostas apresentadas. Conforme destaca Oliveira:

\begin{abstract}
Em relação aos homossexuais, Eliel Rodrigues iniciava a defesa de sua proposta sempre apoiado em justificativas religiosas. Relacionava em sua fala os casos de AIDS ao fato de homens deixarem "o uso natural da mulher" para relacionarem se com outros homens. Sua fundamentação foi completamente retirada da Bíblia, não apresentando nenhuma outra justificativa para que o texto Constitucional não vedasse a discriminação de homossexuais pela expressão "orientação sexual". Costa Ferreira completava o argumento, afirmando que os homossexuais deveriam ser "recuperados" ou deveriam ter a chance de abandonar essa vida para se casar, pois em sua concepção, a mulher seria talhada para exercer um papel feminino, complementando o homem (OLIVEIRA, 2013).
\end{abstract}

Conforme já citado acima, tal proposta foi negada por 130 votos a favor e 317 contras. Apesar desta derrota, os movimentos deram continuidade, e, a partir desta mobilização, o movimento conquistou que fosse constado expressamente a proibição de discriminação por orientação sexual nas Cartas Políticas de mais de 80 municípios (num universo de mais de 5.500 municípios) e dez Estados (MASIERO, 2017, p. 76-96). 
Outrossim, cabe destacar o artigo $5^{\circ}$ da Lei 11.340/2006, conhecida como Lei Maria da Penha, que deixa claro que a violência doméstica independe da orientação sexual, conforme abaixo:

Art. 5 Para os efeitos desta Lei, configura violência doméstica e familiar contra a mulher qualquer ação ou omissão baseada no gênero que lhe cause morte, lesão, sofrimento físico, sexual ou psicológico e dano moral ou patrimonial: (Vide Lei complementar $n^{\circ}$ 150, de 2015)

I - no âmbito da unidade doméstica, compreendida como o espaço de convívio permanente de pessoas, com ou sem vínculo familiar, inclusive as esporadicamente agregadas;

II - no âmbito da família, compreendida como a comunidade formada por indivíduos que são ou se consideram aparentados, unidos por laços naturais, por afinidade ou por vontade expressa;

III - em qualquer relação íntima de afeto, na qual o agressor conviva ou tenha convivido com a ofendida, independentemente de coabitação.

Parágrafo único. As relações pessoais enunciadas neste artigo independem de orientação sexual. (grifou-se) (BRASIL, 2006).

Já para Rios, a menção ao critério sexo no artigo. $3^{\circ}$, inciso IV, da Constituição Brasileira, já albergaria a orientação sexual e identidade de gênero, pois estaria implicitamente inserido tal tratamento discriminatório, pois "o fator decisivo para a ocorrência da discriminação é a combinação dos sexos das pessoas envolvidas (homem envolvido com homem é tratado diferentemente de homem com mulher) (RIOS, 2008, p. 57).

No ano de 2001, a então Deputada lara Bernardi apresentou o Projeto de Lei 5.003, de 2001, que objetivava a promulgação em lei específica para as condutas de discriminação baseada na orientação sexual. Em 2006, o projeto foi designado como PLC 122/2006, tendo sido alterado o objetivo para a inclusão na Lei 7.716/89, que define os crimes resultantes de preconceito de raça ou de cor, da proibição à discriminação ou preconceito de gênero, sexo, orientação sexual, identidade de gênero (OLIVA, 2015, p. 211).

A PLC 122/2006 que era chamada de Lei da Mordaça Gay, por seus opositores, tinha a seguinte explicação da ementa:

Explicação da Ementa: Altera a Lei n 7.716, de 5 de janeiro de 1989, o Decreto-Lei $n^{\circ}$ 2.848, de 7 de dezembro de 1940 (Código Penal) e o Decreto-Lei nº 5.452, de $1^{\circ}$ de maio de 1943 (Consolidação das Leis do Trabalho - CLT) para definir os crimes resultantes de discriminação ou preconceito de gênero, sexo, orientação sexual e identidade de gênero. Estabelece as tipificações e delimita as responsabilidades do ato e dos agentes (BRASIL, 2006). 
Necessário se torna citar que o PLC 122/2006 foi arquivado após morosa análise, tendo tramitado no Congresso por mais de 9 anos, sendo 6 no Senado, analisado por três comissões, sendo que em 17 de dezembro de 2013 houve a anexação do PLC ao Projeto de Lei do Senado 236 de 2012, que versa sobre a reforma do Código Penal Brasileiro, que permanece em tramitação (OLIVA, 2015, p. 213).

Tal Projeto de Lei foi muito criticado pela conhecida Bancada Evangélica, por considerarem que tal projeto limitaria a liberdade religiosa e elevaria os homossexuais a um nível maior de consideração, ou seja, haveria direitos especiais somente aos homossexuais. Todavia, o que se tentou criar com o projeto de lei foi o respeito à orientação sexual de cada um (CARRARA, 2010, p. 312-368).

Ademais, isso não acarretaria nenhum direito especial ao homossexual, bissexual ou transexual, e sim, somente uma garantia a essa parcela dos brasileiros, que em todas as ocasiões, nos desafios da vida civil, o comportamento partiria do mesmo dos demais, e o tratamento seria o mesmo. Nas palavras de Abílio:

Ao determinar que ninguém pode ser discriminado com base na sua orientação sexual, o projeto não cria uma "casta privilegiada", como vem sendo difundido no meio televisivo e eletrônico. Determina que homossexuais, bissexuais e heterossexuais terão sua orientação sexual respeitada (ABILIO apud CARRARA, 2010, p. 312-368).

No dia 23 de novembro de 2017 foi entregue à presidente da Comissão de Direitos Humanos e Legislação Participativa (CDH), Senadora Regina Sousa, o Anteprojeto do Estatuto da Diversidade Sexual e Gênero. $O$ Estatuto foi formulado pela OAB através de suas Comissões Especiais da Diversidade Sexual. Junto com o Anteprojeto, foram entregues também 100 mil assinaturas colhidas ao longo do período de 6 anos como forma de apresentação por iniciativa popular (BRASIL, 2017a).

Na Exposição de Motivos do Estatuto da Diversidade Sexual há a expressa menção ao princípio da dignidade da pessoa humana, da liberdade e da igualdade, todos constantes na nossa Carta Magna, com a ressalva de que a legislação infraconstitucional deve dar a efetividade a esses princípios e normas. Também cita a omissão do Estado em proporcionar proteção às pessoas homossexuais, o que acabou por ensejar várias demandas ao Poder Judiciário. Citam-se algumas, como, por exemplo, reconhecimento a direitos previdenciários, direito à herança, adoção, direito real de habitação, de forma que em sede administrativa já há também algumas conquistas, como a concessão pelo INSS de pensão por morte e auxílio reclusão, sem necessidade de ação judicial, a inclusão do companheiro como dependente no Imposto de Renda (DIAS, 2016, p. 329).

Vale aqui mencionar a decisão do STF, na ADI 4.277 e ADPF 132, que por unanimidade reconheceu as uniões homoafetivas como entidades familiares. Se trata de grande conquista, porém ainda carente 
de legislação, pois não cabe ao Judiciário legislar, ele inclusive incitou o Legislativo a cumprir seu papel neste caso, porém, sem avanços até o momento. Segundo Dias, o Judiciário "simplesmente cumpriu o seu encargo de julgar, suprimindo as lacunas da lei". Ademais, em relação à criminalização da homofobia, há ainda alguns projetos de lei ou emendas constitucionais que tramitam nas casas legislativas, sem nenhum ou com muito pouco avanço, fora os já arquivados (DIAS, 2016, p. 330-331).

Após o arquivamento da PLC 122/2006, houve no Senado, no ano de 2016, uma sugestão popular novamente com o projeto de equiparar o crime de racismo ao de discriminação por orientação sexual e identidade de gênero, alterando os artigos $1^{\circ}, 3^{\circ}, 4^{\circ}, 8^{\circ}$ e 20 da Lei 7.716 de 5 de janeiro de 1989. 0 relator desta sugestão é o Senador Paulo Paim, e a sugestão foi apresentada por Gustavo Don e teve o apoio de mais de 22.000 cidadãos. Tal sugestão está em tramitação, tendo como numeração Sugestão n 5, de 2016 (BRASIL, 2016).

Já no ano de 2017, outra proposta de um cidadão recebeu mais que o dobro do solicitado para que uma Ideia Legislativa se torne uma Sugestão Legislativa. Lucas Veiga Couto propôs no portal e-Cidadania, do Senado Federal, a Ideia Legislativa de punição a quem praticar ofensa física ou moral contra outra pessoa em virtude de sua orientação sexual. De acordo com o site do Senado Federal, até outubro de 2017 a proposta já contava com 52.522 manifestações de apoio (BRASIL, 2017b).

Ainda, encontra-se em análise no STF o Mandado de Injunção 4.733/DF que foi impetrado pela Associação Brasileira de Lésbicas, Gays, Bissexuais, Travestis e Transexuais (ABGLBT) e a Ação Direta de Inconstitucionalidade por Omissão 26/DF (ADO 26), intentada pelo Partido Popular Socialista (SILVA e BAHIA, 2015, p. 177-207).

Consoante a petição inicial, a ADO 26 propõe:

[...]obter a criminalização específica de todas as formas de homofobia e transfobia, especialmente (mas não exclusivamente) das ofensas (individuais e coletivas), dos homicídios, das agressões e discriminações motivadas pela orientação sexual e/ou identidade de gênero, real ou suposta, da vítima, por ser isto (a criminalização específica) decorrência da ordem constitucional de legislar relativa ao racismo (art. $5^{\circ}$, XLII) ou, subsidiariamente, às discriminações atentatórias a direitos e liberdades fundamentais (art. $5^{\circ}, \mathrm{XLI}$ ) ou, ainda subsidiariamente, ao princípio da proporcionalidade na acepção de proibição de proteção deficiente (art. 5, LIV, da CF/88).

Esta ação se fundamenta no julgamento do Habeas Corpus 82.424/RS que discutiu se manifestações antissemitas seriam ou não crime de racismo. Neste julgamento, o STF cunhou um novo conceito de racismo, com cunho político-social, e não biológico. Desta forma, racismo seria a superioridade de um grupo sobre outro, independente de origem, raça, orientação sexual ou qualquer outra forma de 
discriminação (SILVA e BAHIA, 2015, p. 177-207).

O Mandado de Injunção 4.733 pretende, basicamente, os mesmos pedidos da ADO, porém com o fundamento de que a criminalização da homofobia e da transfobia se faz necessária, haja vista que tais fatos prejudicam essas minorias de desfrutar dos mesmos direitos dos heterossexuais. Com base nisto, 0 que se verifica é que ambas as ações pedem o reconhecimento da omissão inconstitucional do Congresso Nacional em criminalizar atos homofóbicos (SILVA; BAHIA, 2015, p. 177-207).

Ainda, é importante referir o Projeto de Lei 7.582/2014, de autoria de Maria do Rosário, que visa a definir os crimes de ódio e intolerância e criar mecanismos de coibição. Neste Projeto de Lei, em seu artigo $2^{\circ}$, consta referência à orientação sexual, identidade e expressão de gênero, entre outras características, como idade, religião, origem social, etc., bem como define o crime de ódio da seguinte forma, em seu artigo $3^{\circ}$ :

Art. $3^{\circ}$ - Constitui crime de ódio a ofensa à vida, à integridade corporal ou à saúde de outrem motivada por preconceito ou discriminação em razão de classe e origem social, condição de migrante, refugiado ou deslocado interno, orientação sexual, identidade e expressão de gênero, idade, religião, situação de rua e deficiência (ROSÁRIO, 2014).

Por fim, seu artigo $5^{\circ}$ conta com a definição de discurso de ódio:

Art. $5^{\circ}$ Praticar, induzir ou incitar a discriminação ou preconceito, por meio de discurso de ódio ou pela fabricação, comercialização, veiculação e distribuição de símbolos, emblemas, ornamentos, distintivos ou propaganda, por qualquer meio, inclusive pelos meios de comunicação e pela internet, em razão de classe e origem social, condição de migrante, refugiado ou deslocado interno, orientação sexual, identidade e expressão de gênero, idade, religião, situação de rua e deficiência (ROSÁRIO, 2014).

Conforme Maria do Rosário, em sua justificativa, a proposta visa proteger os grupos que não foram contemplados na Lei do Racismo, e que permanecem sem a devida proteção contra as discriminações, sendo que as condutas apresentadas no projeto são condutas violadoras de Direitos Humanos, e que obrigam o Estado a adotar medidas protetivas a essas vítimas de discriminação e intolerância. Tal projeto teve como última tramitação o envio à Comissão de Direitos Humanos e Minorias em 11/07/2017 (ROSÁRIO, 2014).

Ainda, é importante referir que o Brasil, desde o ano de 2001, conta com o Conselho Nacional de Combate à Discriminação e Promoção dos Direitos de Lésbicas, Gays, Bissexuais, Travestis e Transexuais (CNCD/LGBT). Tal Conselho é um órgão colegiado integrante da Secretaria de Direitos Humanos da Presidência da República. No site do Conselho, consta a informação de que a finalidade de tal órgão 
desponta justamente da demanda histórica do movimento LGBT. O Brasil conta com o relatório do governo, sendo o mais atual do ano de 2013. Ele foi feito a partir de dados hemerográficos, ou seja, através de notícias veiculadas pela imprensa, que foram disponibilizados pelo Grupo Gay da Bahia, que faz um levantamento de tais crimes desde 2011. Porém, no site do GGB consta o relatório do ano de 2017 que concluiu que, a cada 19 horas, 1 pessoa é assassinada no Brasil por motivos homofóbicos. Um aumento de cerca de 30\% em relação a 2016 (BRASIL, 2017c).

O que se verifica, após esta breve explanação dos projetos de criminalização da homofobia, é que desde a assembleia constituinte, em 1987, já se falava em criminalizar a homofobia, porém, o que se observa é uma clara e expressiva morosidade da política brasileira em encontrar uma solução para este conflito. Não há como negar que o preconceito é a grande chave para esta morosidade. 0 que realmente se constata é que mesmo que aleguem que uma eventual lei que criminalize a homofobia ou o discurso de ódio seja uma censura à liberdade de expressão, principalmente a religiosa, tal parcela da população merece 0 mesmo tratamento que os heterossexuais. 0 que pode ser discutido é a forma de alcance dessa igualdade, se é legítimo criminalizar a homofobia e qual forma seria a mais adequada, conforme será visto a seguir. Ademais, o próprio governo confirma que há, sim, uma demanda histórica em relação à homofobia, que, por conseguinte, deve ser reconhecida - porque não? - da mesma forma que outras minorias.

\subsection{LEGITIMIDADE PARA CRIMINALIZAR A HOMOFOBIA}

Após o breve histórico dos projetos já apresentados, arquivados ou ainda em movimentação que versam sobre a criminalização da homofobia, cabe analisar se seria legítima a criminalização e qual seria a melhor forma para tal feito. A luta pela igualdade racial se deu através da punição do racismo, a igualdade sexual também busca a punição, mas a pergunta é se seria a punição através do sistema penal a melhor forma para os LGBTI atingirem a igualdade.

No ano de 2008, a OEA (Organização dos Estados Americanos) aprovou a Resolução AG/RES. 2435 (XXXVIII-0/08) sobre direitos humanos, orientação sexual e identidade de gênero. Tal Resolução, que afirma que as mesmas proteções que têm os direitos humanos devem ser estendidas à orientação sexual e identidade de gênero, foi aprovada de forma unânime, sendo o Brasil o país que apresentou o projeto. Já no ano de 2011, a ONU editou uma Resolução no Conselho de Direitos Humanos, n A/HRC/17/L.9, em que afirmou que os direitos LGBTI são também direitos humanos. Esta Resolução foi aprovada pelo Brasil, sendo considerado um marco para a história da comunidade LGBTI (GORISCH, 2014, p. 43-45).

Em 2014, a ONU editou nova Resolução no Conselho de Direitos Humanos, n A/HRC/27/L.27/ Rev.1, em que expressa a sua preocupação com os atos de violência e discriminação contra os LGBTI. 
Novamente o Brasil votou a favor, inclusive sendo um dos países que apresentou o projeto, onde afirmou que os Estados devem combater essa forma de violação dos direitos humanos (ONU, 2014).

Relevante assinalar a campanha da ONU Free \& Equal United Nations (Livres e Iguais), que tem como objetivo promover a igualdade e o tratamento justo às pessoas LGBTI. Tal campanha conta com uma cartilha de 60 páginas, cujo título é "Nascidos Livres e Iguais", que serve como ajuda aos Estados para compreensão de suas obrigações para o real cumprimento dos direitos humanos das pessoas LGBTI (ONU, 2017).

No Brasil, há a discussão sobre se a criminalização da homofobia é viável, legítima e oportuna, e tal discussão gira em torno de que a discriminação da orientação sexual é uma afronta ao princípio da igualdade, porém, há os defensores de que uma possivel tutela penal em relação a tal tema acabe por impor um limite à liberdade de expressão. Conforme aponta a autora Flavia Medeiros:

[...] não diferenciação com base na orientação sexual como respeito à dignidade humana, garantida no art. $1 .^{\circ}$ da CF/1988 (LGLI1988\3), reforçada pelos princípios da igualdade e da liberdade (2000, p. 267). 0 impedimento discriminatório está previsto na Convenção Internacional sobre Direitos Civis e Políticos e na Convenção Americana sobre Direitos Humanos - Pacto de San José da Costa Rica (dos quais o Brasil é signatário), e, além disso, a ONU repudia interferência na vida privada de homossexuais adultos, por considerar afronta à dignidade humana e igualdade (MEDEIROS apud CARRARA, 2010, p. 312-368).

Em síntese, Carrara leciona que "a igualdade, além de princípio fundamental, está garantida no art. $5^{\circ}$ da CF/1988 (LGL\1988\3), como direito fundamental. Os direitos fundamentais não são garantias do indivíduo apenas perante o Estado, mas entre os próprios indivíduos" (CARRARA, 2010, 312-368).

Em que pesem tais entendimentos, o que verificamos, na realidade, são equívocos ou falta de entendimento sobre a questão de direito, democracia e moral. Tais conclusões podem ser detectadas em declarações como a do Juiz de Direito Marcos Augusto Barbosa dos Reis, sobre a união homoafetiva: "O Brasil não está preparado para a união civil. É desnecessária e contraria as bases culturais e religiosas do país. "Bem como, a declaração do advogado Jaques de Camargo Penteado: "nem o direito natural e nem a legislação constitucional e infraconstitucional brasileiras preveem a união homossexual. [...] essas decisões isoladas jamais significarão que dois ou duas pessoas possam encontrar a felicidade e a proteção do direito a partir de uma conduta que é um desvio da natureza das coisas." (LOPES, 2011, p. 21).

As declarações acima revelam que há, sim, um fator de limitação de direitos de cidadania, aos direitos humanos, entre outros, fazendo com que o princípio constitucional de não discriminação e o princípio da igualdade não se apliquem a essa parcela da população (MASIERO, 2017, p. 121).

Carvalho indaga se seria legítimo ao Estado Democrático de Direito a diferença entre crimes em geral 
dos crimes praticados por preconceito ou discriminação em virtude da orientação sexual ou identidade de gênero. Esclarece mais o autor quando levanta o questionamento sobre se do "ponto de vista da construção histórica dos direitos humanos esta diferenciação qualitativa estaria adequada e justificada constitucionalmente." (CARVALHO, 2012, p. 187-212).

Ademais, Carvalho visualiza a questão conforme a linguagem proposta por Ferrajolli: "o princípio de ofensividade permite considerar como 'bens' (jurídicos - penais) apenas aqueles cujas lesões se concretizam em uma ofensa contra pessoa de carne e osso (FERRAJOLI apud CARVALHO, 2012, p. 187-212).

Acerca da tutela penal, Copello afirma que a marginalização e a desvalorização de determinados grupos provocam um perigo claro de ter seus direitos básicos ignorados e, com isso, o direito penal deve considerar como adicional este risco, ou seja, cabe ao direito penal tutelar certos grupos que estão sujeitos a perigos que outros grupos não estão. 0 direito penal deve estar vigilante aos fatores de gravidade e difícil prevenção, que é o que legitima a intervenção penal (COPELLO apud CARRARA, 2010, p. 312-368).

Masiero questiona se cabe à homofobia um tratamento por legislação específica e de natureza penal, porém, em suas palavras:

"É de se reconhecer que há permissão constitucional para a tutela da igualdade em razão da orientação sexual, haja vista tratar-se de corolário da autodeterminação e do princípio da dignidade da pessoa humana. Constituindo-se, portanto, em bem jurídico passível de tutela penal (MASIERO, 2017, p. 123-124).

Em relação a tal questionamento, Díez Ripollés pontua que "as representações mentais evocadas pelo direito penal, para serem legítimas, devem coincidir materialmente com o pensamento da maioria dos cidadãos". Também expõe que não cabe à intervenção penal alterar crenças e valores (RIPOLLÉS, 2010, p. 312-368).

É sabido que a cultura heterossexista permeia a sociedade e, desta forma, levando em consideração o citado acima, uma eventual criminalização da homofobia não seria o pensamento da maioria, além de indicar prejudicial e, até mesmo, arbitrária e autoritária perante o seio social. Todavia, Masiero destaca que "não se pode, entretanto, sobrepor este raciocínio à questão da criminalização da homofobia, uma vez que a igualdade e a dignidade humana são valores consensuais (e expressos na constituição) da sociedade brasileira (ainda que não plenamente efetivados)". (MASIERO, 2017, p. 124-125).

Outrossim, conforme bem assinala Lopes, "não é uma luta pelo convencimento da maioria quanto ao valor de uma minoria, mas uma luta pelo pluralismo". (LOPES, 2011, p. 46).

Ainda em relação à criminalização, o que se constata é que os tipos penais que se classificam com a homofobia já se encontram no sistema penal, quais sejam, a injúria, a lesão corporal, homicídio, entre 
outros. Isto posto, não haveria que se criminalizar novas condutas, mas, sim, verificar a necessidade de uma nova diferenciação qualitativa (MASIERO, 2017, p. 126).

Rios entende que, partindo do ponto de vista do Direito da Antidiscriminação, "a injustiça cultural ou simbólicaexigereconhecimentodosgruposestigmatizados, numadinâmicadiferenciadoraeparticularista" (RIOS, 2007, p.171), por sua vez, Carvalho entende que "a defesa de uma especificação legal (nomen juris) da violência homofóbica decorre da necessidade de nominação e do consequente reconhecimento formal do problema pelo Poder Público, retirando-o da invisibilidade e da marginalização". E acrescenta:

Do ponto de vista da construção histórica dos direitos humanos, os grupos LGBTs possuem a mesma legitimidade postulatória para efetivação de suas pautas políticas (positivas e negativas) que, por exemplo, o movimento de mulheres e o movimento negro. [...] Entendo que é fundamental reconhecer a existência de um passivo histórico na cultura ocidental que legitima formas distintas de tutela jurídica destes grupos vulneráveis. Não apenas pela violência interpessoal, fruto da cultura misógina, racista e homofóbica, que se presentifica e se atualiza no cotidiano, mas, sobretudo, pelo fato de terem sido instituídas formalmente políticas de Estado voltadas à eliminação e à segregação destas diferenças - por exemplo, o controle punitivo e violento sobre o corpo feminino no Medievo (misoginia de Estado); as políticas escravagistas na época colonial (racismo de Estado); a criminalização e a patologização da homossexualidade na história recente (homofobia de Estado) (CARVALHO, 2012, p. 187-212).

Contudo, há também o entendimento de que, neste viés, o direito penal estaria exercendo um papel simbólico e com efeito negativo sobre o enfrentamento da criminalização da homofobia, acentuando a ideia de inferioridade e dissimulando a discriminação (MASIERO, 2017, p. 126/127).

Porém, pode-se destacar que a tutela penal da homofobia teria um caráter até mesmo pedagógico, visto que o simples fato de ser crime qualquer forma de discriminação por conta da orientação sexual poderia transmitir à sociedade a ideia de que discriminar é nocivo. Isto seria visto com as novas gerações que nasceriam já sob a égide de que existe uma conduta tipificada como crime em caso de discriminação por orientação sexual, como já percebido no caso do racismo, onde as últimas gerações já têm a plena noção de que racismo é crime (CARRARA, 2010, p. 312-368).

Cabe ressaltar que a criminalização da homofobia recebe duras críticas de religiosos, que consideram que terão suas liberdades religiosa e de expressão tolhidas. Todavia, conforme bem destaca Carrara, "não se pode permitir é que, em nome das religiões, continuem sendo propagadas agressões explicitamente movidas de ódio, repulsa e desejo de limpeza e exorcismo". Ademais, o Brasil sendo um Estado laico, não poderia permitir que a ideia de doença, por exemplo, fosse ainda vinculada à homossexualidade, haja vista a medicina já ter definido a não patologia. Por fim, vale dizer que a discriminação baseada na religião 
já é criminalizada, nos mesmos termos que a homofobia tenta ser (CARRARA, 2010, p. 312-368).

Outrossim, sobre a estratégia usada pelo movimento LGBTI quanto à criminalização da homofobia, Carvalho entende que há legitimidade, porém, afirma:

A técnica legislativa poderia ser restrita à identificação desta forma de violência - sem qualquer ampliação de penas, objetivando exclusivamente dar visibilidade ao problema - através da remissão da sanção ao preceito secundário do tipo penal genérico - por exemplo, caput do art. 121 d CP: 'matar alguém: Pena - reclusão de 6(seis) a 20 (vinte) anos'; inclusão de parágrafo intitulado homicídio homofóbico: 'nas mesmas penas incorre quem praticar a conduta descrita no caput por motivo de discriminação ou preconceito de gênero, sexo, orientação sexual e identidade de gênero'. No máximo, seguindo o caminho trilhado pela Lei Maria da Penha, a inserção da motivação homofóbica como causa de aumento de pena no rol das agravantes genéricas (CARVALHO, 2012, p. 187212).

Sobre este entendimento, Masiero corrobora:

Por meio da legítima denominação da violência homofóbica, não seria necessário criar novos tipos penais, bastando a identificação e a adjetivação de determinados crimes, quando motivados pelo preconceito ou discriminação de orientação sexual, como crime homofóbico. Isto significa que, mesmo dentro de uma pauta minimalista de política criminal, seria possivel despender de uma tutela penal para a homofobia (MASIERO, 2017, p. 126/127).

Desta maneira, Carvalho entende que a via eleita (a inclusão da homofobia na Lei $7.716 / 1989$ ) foi bastante inadequada, tendo em vista que solve a ideia de preconceito e discriminação por orientação sexual e identidade de gênero nas questões de raça, cor, religião etnia e procedência nacional. Outrossim, as condutas tipificadas nesta lei versam, em grande parte, por assuntos que poderiam se desenvolver na esfera civil, trabalhista, consumerista ou administrativa (CARVALHO, 2012, p. 187-212).

Ademais, a Lei 10.471/2013 incluiu no Código Penal o crime de injúria racial, uma qualificadora específica em caso de preconceito de cor ou raça, fazendo com que o racismo fosse nominado dentro do Código Penal. Desta maneira, Masiero afirma que: "a tutela penal da homofobia pode contribuir para a prevenção e o enfrentamento da homofobia e que para tanto é desnecessária a criação de novos tipos penais". (MASIERO, 2017, p. 147).

Como último ponto, neste contexto de repressão, antes de tal fato, a luta contra a homofobia pede uma ação pedagógica com fulcro a mudar a imagem ancestral de que a heterossexualidade e o binarismo de gênero são as únicas possibilidades naturais e que a homossexualidade se trata de uma disfunção moral e afetiva. O fundamento da reprodução da espécie não justifica mais tal julgamento. Isto posto, 
a homofobia, enquanto problema social, deve ser encarada como um delito passível de sanção jurídica; não obstante, reprimir sem acompanhamento de ação preventiva se torna sem sentido (BORILLO, 2015, p. 106).

O direito penal, em sua função simbólica, parece ser a via certa para a criminalização da homofobia, porém, o que se verifica são várias tentativas de projetos para criminalizar a homofobia, todos sem sucesso até o presente momento, o que faz concluir que é nítida a falta de vontade dos legisladores em simplesmente fazer valer a Constituição. Não cabe a esta dissertação analisar qual o melhor expediente para a solução desta controvérsia, mas sim demonstrar como um caso que se pode dizer simples, do ponto de vista da técnica legislativa, sofre tanto com a morosidade. É fato que já houve inúmeras tentativas infrutíferas de criminalizar a homofobia, e que há legitimidade para a criminalização dos crimes de cunho homofóbicos, porém, o que se observa é um emaranhado de ideias, todas apontando para o mesmo objetivo final, criminalizar a homofobia, contudo, distantes ainda deste objetivo. Ademais, além de criminalizar, devem-se planejar ações de prevenção e educação quanto ao tema homossexualidade, a fim de que, no futuro, haja um entendimento de que não há diferenças entre heterossexuais e homossexuais.

\section{CONSIDERAÇÕES FINAIS}

No decorrer do presente artigo, procurou-se demonstrar a possibilidade jurídica de criminalização da homofobia, haja vista a ligação da homofobia com o discurso de ódio. Ainda, no caminho de preceitos para corroborar com o objeto principal, utilizou-se de análise do discurso de ódio e da liberdade de expressão.

Com isto, fez-se uma breve análise acerca dos projetos de lei já apresentados, que versaram sobre a criminalização da homofobia, bem como apresentou-se o Projeto de Lei 7.582/2014, que define crime de ódio. Fato é que desde a assembleia constituinte em 1987 já se falava em criminalizar a homofobia. Contudo, a morosidade legislativa é extrema. O que se verifica, então, é a passagem do "bastão" ao Poder Judiciário, novamente, assim como ocorreu com a união homoafetiva, que se deu através de decisão do STF. Mas não cabe ao Judiciário legislar, e sim ao legislativo, através das já inúmeras propostas apresentadas, inclusive pela população, que usou o portal e-Cidadania para apresentar Ideia Legislativa, que em outubro de 2017 já recebia mais de 50 mil manifestações de apoio, sendo que, acima de 20 mil, a ideia se torna uma Sugestão Legislativa, que é debatida pelos Senadores. Não obstante a alegação de censura à liberdade de expressão já citada, tal parcela da população merece o mesmo tratamento de igualdade dado aos heterossexuais.

Acerca desta justificativa citada acima, da censura à liberdade de expressão, urge citar o fato da "laicização" do Estado brasileiro. A nossa Constituição Federal deixa claro nos artigos $5^{\circ}$ e 19, inciso I, que 
a República do Brasil é laica, assim como é assegurado ao cidadão ter ou não uma religião. Porém, o que vemos é que a bancada religiosa é maioria na Câmara de Deputados, o que faz com que os Projetos de Lei que visam proteger os direitos dos homossexuais tenham grande resistência e, por fim, conforme exposto neste trabalho, acabam sendo arquivados. Ou seja, estamos mesmo num Estado laico?

Mesmo com todas as explanações e demonstrações da diferença de tratamento empregadas entre os heterossexuais e os homossexuais, de fato, está mais do que comprovado que esta suposta diferença não existe. Negar direitos aos homossexuais é um atentado aos direitos humanos, principalmente o direito à igualdade. Estas minorias sexuais já foram alvo de perseguições pela religião, psiquiatria, psicologia e até mesmo pela lei. Dito isto, assim como as mulheres que tiveram que lutar pelos seus direitos, as minorias sexuais lutam agora pelos seus direitos. Desta forma, o que se mostra aqui neste artigo, e que se torna vital, é que o simples reconhecimento de igualdade e dignidade, princípios norteadores do nosso país, eleva o homossexual a ser merecedor de respeito e liberdade, como qualquer outra pessoa, em sua plenitude. E é isto o que não vemos no Brasil. O simples fato de uma pessoa LGBTI querer exercer o seu direito de igualdade e não aceitar o preconceito com a alegação do preconceituoso de estar exercendo seu direito de liberdade de expressão não é elevar o homossexual acima do heterossexual, mas simplesmente elevar ao mesmo patamar.

Ademais, não há como deixar de citar que, ao nascermos, somos dotados de direitos e obrigações, nos tornamos capazes, conforme bem preceitua o nosso Código Civil. Então, o fato de não nos enquadrarmos mais no considerado erroneamente como "normal" permite a exclusão de direitos?

Conclui-se então que, mesmo que haja uma eventual decisão do STF em relação às ações apresentadas neste trabalho e que ainda estão em tramitação, nada superará uma Lei que determine o respeito ao diferente, em conjunto com ações de educação, fazendo valer, assim, a dignidade da pessoa humana. Contudo, enquanto a morosidade do Legislativo perdurar, cabe ao STF agir. Em que pese o limite e respeito entre os três Poderes, a Corte Superior tem o dever de interpretar a Constituição a fim de resguardar o direito; e se, por motivos religiosos, o Legislativo não age, o STF nada mais faz do que o que a nossa Constituição estabelece. Desta forma, chegará o dia em que LGBTI e heterossexuais serão considerados iguais, em direitos e obrigações, desde sempre. Afinal, o brasileiro precisa de uma lei, de caráter jurídica e também social, para, muito lentamente, termos uma sociedade livre de preconceitos ou discriminações.

\section{REFERÊNCIAS}

BORILLO, Daniel. Homofobia: História e crítica de um preconceito. Tradução de Guilherme João de Freitas Teixeira. 1 ed. 2 reimp. Belo Horizonte: Autêntica, 2015.

BRASIL. Presidência da República. Lei 11.340, de 7 de agosto de 2006. Disponível em: <http://www. 
planalto.gov.br/ccivil_03/_ato2004-2006/2006/lei/l11340>.htm. Acesso em: 23 nov. 2017.

BRASIL. Senado Federal. CDH recebe proposta do Estatuto da Diversidade Sexual. Disponível em: <https://www12.senado.leg.br/noticias/materias/2017/11/23/cdh-recebe-proposta-do-estatuto-dadiversidade-sexual>. Acesso em: 28 nov. 2017.

BRASIL. Senado Federal. Projeto de Lei da Câmara n 122, de 2006. Disponivel em: <https://www25. senado.leg.br/web/atividade/materias/-/materia/79604>. Acesso em: 28 nov. 2017.

BRASIL. Senado Federal. Senado pode voltar a examinar proposta que torna crime a homofobia. Disponivel em: <https://www12.senado.leg.br/noticias/materias/2016/09/29/senado-pode-voltar-aexaminar-proposta-que-torna-crime-a-homofobia>. Acesso em: 28 nov. 2017.

BRASIL. Senado Federal. Ideia Legislativa propõe criminalização da homofobia e recebe mais de $\mathbf{5 0}$ mil apoios. Disponivel em: <https://www12.senado.leg.br/noticias/materias/2017/06/28/ideia-legislativapropoe-criminalizacao-da-homofobia-e-recebe-mais-de-50-mil-apoios>. Acesso em: 28 nov. 2017.

BRASIL. Ministério dos Direitos Humanos. Relatórios de violência LGBTfóbica. Disponivel em: <http:// www.mdh.gov.br/navegue-por-temas//gbt/biblioteca/relatorios-de-violencia-Igbtfobica>. Acesso em: 30 mai. 2018.

BRASIL. SUPREMO TRIBUNAL FEDERAL. Acompanhamento Processual: AD0/26. Disponivel em: <http:// redir.stf.jus.br/estfvisualizadorpub/jsp/consultarprocessoeletronico/ConsultarProcessoEletronico. jsf?seqobjetoincidente=4515053> Acesso em: 28 nov. 2017.

CARRARA, Mariana Salomão. Ponderações sobre a Criminalização de condutas homofóbicas. Revista Brasileira de Ciências Criminais. v. 84, p. 312-368, mai./jun. 2010. Disponível em: <http://www.revistadostribunais.com.br/maf/app/resultList/document?\&src=rl\&srguid=iOad82d9a0000016003b6344be19955dc\&docguid=Ic4a952302d4111e0baf30000855dd350\&hitguid=lc4a952302d4111eObaf$30000855 \mathrm{dd} 350 \&$ spos $=2 \&$ epos $=2 \& \mathrm{td}=4 \&$ context=6\&crumb-action=append\&crumb-label=Documento\&isDocFG=true\&isFromMultiSumm=true\&startChunk=1\&endChunk=1>. Acesso em: 28 nov. 2017.

CARVALHO, Salo. Sobre a Criminalização da Homofobia: perspectivas desde a criminologia Queer. Revista Brasileira de Ciências Criminais, v. 99, p. 187-212, nov./dez. 2012. Disponível em: <http://www.revistadostribunais.com.br/maf/app/resultList/document?\&src=rl\&srguid=iOad82d9b0000015f8d865448ff69cccc\&docguid=lae20fae02eed11e29b42010000000000\&hit- 
guid=lae2Ofae02eed11e29b42010000000000\&spos=1\&epos=1\&td=24\&context=4\&crumb-action=append\&crumb-label=Documento\&isDocFG=true\&isFromMultiSumm=true\&startChunk=1\&endChunk=1>. Acesso em: 21 nov. 2017.

DIAS, Maria Berenice. Homoafetividade e direitos LGBTI. 7 ed. Ver., atual. e ampl. São Paulo: Revista dos Tribunais, 2016.

GORISCH, Patrícia. 0 reconhecimento dos Direitos Humanos LGBT: De Stonewall à ONU. Curitiba: Appris, 2014.

JUNQUEIRA, Rogério Diniz. Homofobia: limites e possibilidades de um conceito em meio a disputas. Bagoas - Estudos gays: gêneros e sexualidades. Natal, v. 1, n. 1, p. 8-9, jul/dez. 2007. Disponível em: <https://periodicos.ufrn.br/bagoas/article/view/2256>. Acesso em: 21 nov. 2017.

LOPES, José Reinaldo de Lima. O Direito ao reconhecimento para gays e lésbicas. In: RIOS, Roger Raupp; GOLIN, Célio; LEIVAS, Paulo Gilberto Logo. (ORG.). Homossexualidade e Direitos Sexuais: reflexões a partir da decisão do STF. Porto Alegre: Sulina, 2011.

MASIERO, Clara Moura. $\mathbf{0}$ movimento LGBT e a homofobia: novas perspectivas de polícitas sociais e criminais. 1 ed. Porto Alegre: Criação Humana, 2014.

OLIVA, Thiago Dias. Minorias Sexuais e os limites da liberdade de expressão: o discurso de ódio e a segregação social dos indivíduos LGBT no Brasil. Curitiba: Juruá, 2015.

\section{OLIVEIRA, Adriana Vidal. As discussões sobre gênero no final do século XX e seus impactos na}

Constituição de 1988. Seminário Internacional Fazendo Gênero (10: 2013 : Florianópolis, SC) Fazendo gênero 10 : desafios atuais dos feminismos: anais eletrônicos [recurso eletrônico] / Seminário Internacional Fazendo Gênero; Org. Jair Zandona - Florianópolis : Universidade Federal de Santa Catarina, 2013. Disponivel em: <http://www.fg2013.wwc2017.eventos.dype.com.br/resources/ anais/20/1373330798_ARQUIVO_AsdiscussoessobregeneronofinaldoseculoXXeseusimpactosnaCons tituicaode1988-versaofinal.pdf> Acesso em: 25 nov. 2017.

RIOS, Roger Raupp. O conceito de homofobia na perspectiva dos direitos humanos e no contexto dos estudos sobre preconceito e discriminação. In: RIOS, Roger Raupp (ORG.). Em defesa dos direitos sexuais, Livraria do Advogado. Porto Alegre. 2007

ROSÀRIO, Maria. Projeto de Lei da Câmara n 7.582 de 2014. Define os crimes de ódio e intolerância 
e cria mecanismos para coibi-los, nos termos do inciso III do art. 1 o e caput do art. 50 da Constituição Federal, e dá outras providências. Disponivel em:http://www.camara.gov.br/proposicoesWeb/prop_mos trarintegra?codteor=1254961\&filename=Tramitacao-PL+7582/2014> Acesso em: 06 fev. 2018.

SILVA, Diogo Bacha; BAHIA, Alexandre Gustavo Melo Franco. Necessidade de Criminalizar a homofobia no Brasil: porvir democrático e inclusão das minorias. Revista da Faculdade de Direito UFPR.

Curitiba, v. 60, n 2, p 177-207, maio/ago. 2015. Disponivel em: <http://revistas.ufpr.br/direito/article/ view/38641/26050> Acesso em: 28 nov. 2017.

SMIGAY, Karin Ellen. Sexismo, homofobia e outras expressões correlatas de violência: desafios para a psicologia política. Psicologia em Revista, v. 8, n. 11. p. 32-46, jun. 2002. Disponível em: <http:// periodicos.pucminas.br/index.php/psicologiaemrevista/article/view/136> Acesso em: 11 nov. 2017. 